\title{
New sequence perspective on the Devonian reef complex and the Frasnian-Famennian boundary, Canning Basin, Australia
}

\author{
John M. Kennard \\ Peter N. Southgate \\ Michael J. Jackson \\ Phillip E. O'Brien \\ Bureau of Mineral Resources, Geology and Geophysics, Canberra City, A.C.T. 2601, Australia \\ Nicholas Christie-Blick ] Department of Geological Sciences and Lamont-Doherty Geological Observatory, \\ Ann E. Holmes \\ Columbia University, Palisades, New York 10964
}

J. F. "Rick" Sarg 310 West Wall, Suite 300, Midland, Texas 79701

\begin{abstract}
The application of concepts of sequence stratigraphy to seismic and well data has led to a new understanding of the subsurface Devonian reef complex of the Canning Basin. It demonstrates marked reciprocal sedimentation with lowstand terrigenous sediments largely restricted to the basin and transgressive and highstand carbonate sediments on the platform. Preliminary outcrop studies indicate the potential of these concepts to modify significantly the existing lithostratigraphic and biostratigraphic interpretations of this classic exhumed reef complex, including the stratigraphic context of the Frasnian-Famennian boundary in the Canning Basin.
\end{abstract}

\section{INTRODUCTION}

The development of seismic and sequence stratigraphy has led to fundamental changes in the study and interpretation of sedimentary successions (Vail, 1987; Posamentier et al., 1988; Sarg, 1988; Van Wagoner et al., 1990). Much of the effort has been directed at successions of Mesozoic and Cenozoic age, and sequence stratigraphy has been applied to a more limited extent in older strata. The Canning Basin of northwestern Australia provides an opportunity to combine surface and subsurface sequence stratigraphy in a setting already well known for its Upper Devonian reef complex (Playford, 1980; Playford et al., 1989) where, because of the steep platform margins, sequence geometry is especially well preserved. The reef complex also provides excellent examples of reciprocal sedimentation controlled by base-level changes and of carbonate deposition in the presence of an abundant supply of coarse terrigenous sediment. The pronounced depositional relief of the platforms and the interfingering of carbonate and siliciclastic facies result in markedly diachronous rock units. Sequence analysis suggests that existing lithostratigraphic interpretations of the reefs need to be modified significantly.

\section{TECTONIC SETTING}

The Devonian reef complex crops out as an exhumed linear belt $-350 \mathrm{~km}$ long at the northern margin of the Canning Basin, fringing the Proterozoic Kimberley block (Fig. 1), and forms one of the best-exposed Paleozoic reef belts in the world. The reef complex extends into the subsurface across parts of the Lennard Shelf and forms an outer "barrier" reef trend at the northern margin of the Fitzroy Trough, a series of northwesttrending half-grabens that contain up to $15 \mathrm{~km}$ of Ordovician-Triassic strata. Northeast-trending transfer faults (Gibbs, 1984) define separate compartments within these half-grabens, each compartment characterized by abrupt changes in stratal geometries.

\section{PREVIOUS STUDIES}

The Devonian reef complex has been extensively studied in outcrop (see synthesis in Playford et al., 1989). These studies have led to a widely accepted model for the development of the complex: a Givetian-Frasnian
Pillara cycle characterized by stromatoporoid-coral-cyanobacterial reefs, vertical platform growth, and widespread platform drowning and backstepping, and a Famennian Nullara cycle characterized by cyanobacterial reefs and strongly advancing platforms. The model relates the reef complex to an almost continuous rise in relative sea level; the Pillara-Nullara cycles are separated by a brief regression at the Frasnian-Famennian boundary, and enormous masses of associated terrigenous conglomerate and sandstone (largely underemphasized) are interpreted as fanglomerate complexes that interfinger with the reefs and commonly limit their growth.

Subsurface exploration of the reefs began in the 1950s, but their subsurface character is poorly known, and the temporal and spatial relations of the facies have not been determined. Seismic modeling (Middleton, 1987), however, suggests that the reef model established from outcrop studies can help identify subsurface facies in the Famennian platform, and high-resolution seismic acquisition has recently enabled definition of Frasnian reef facies at shallow $(\sim 1 \mathrm{~km})$ depths (Kemp and Wilson, 1990).

\section{SUBSURFACE SEQUENCE STRATIGRAPHY}

We have mapped 15 Frasnian to Tournaisian sequences and their component systems tracts in the transfer-fault compartment containing the Meda 1 well (Fig. 2). Sequence and systems tract stacking patterns indicate two distinct phases of basin sedimentation: a Frasnian-Famennian reefrimmed platform complex (the subject of this paper) and a FamennianTournaisian ramp complex. The reef complex consists of two cycles of successively onlapping sequences separated by a major basinward shift of

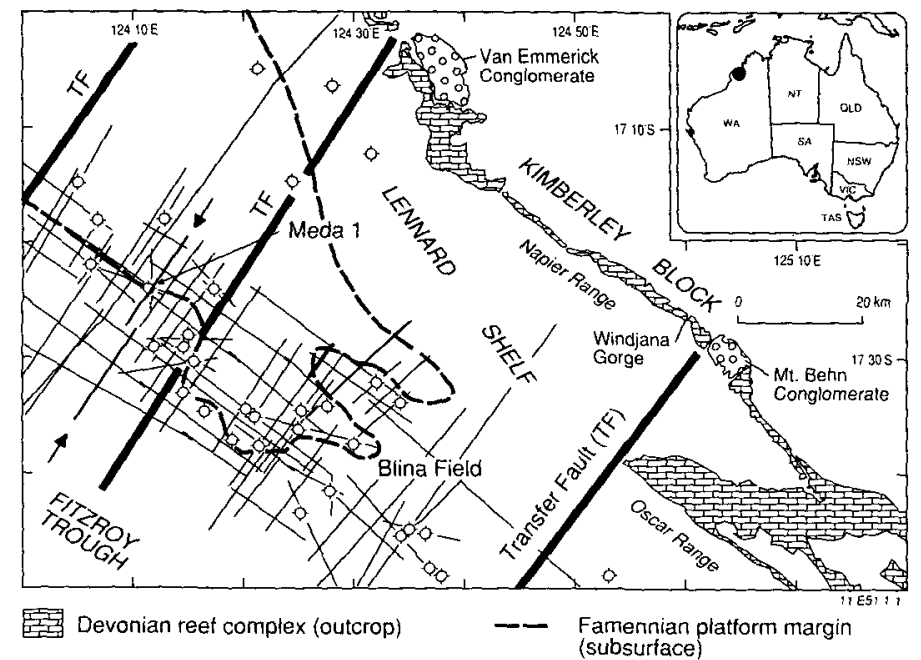

o Exploration well

Figure 1. Study area and seismic grid, northern Canning Basin. Arrows indicate seismic lines shown in Figure 2. 
coastal onlap (Fig. 2); sequences in the lower cycle display successively back-stepping platform margins (Frasnian sequences 1 to 4), whereas sequences in the upper cycle display successively advancing platform margins (Frasnian-Famennian [F-F] sequence and Famennian sequences 1 and 2). These cycles correlate with the Pillara and Nullara cycles previously identified in outcrop. The basinward shift of coastal onlap implies prolonged subaerial exposure of the Pillara cycle prior to marine flooding associated with Famennian sequence 1. This basinward shift of coastal onlap is thought to be controlled in part by basin tectonism since differential subsidence across transfer faults is evident within Frasnian-Famennian strata on seismic strike lines. Each sequence within the reef complex is characterized by reciprocal sedimentation in which lowstand clastic-rich sediments were largely restricted to the basin and highstand carbonate sediments were deposited across the platform and platform margin.

Lowstand deposits are subdivided into three, seismically defined, depositional systems (cf. Posamentier et al., 1991): basin-floor fan, slope fan, and prograding complex. They are intersected in only a few wells, so their lithofacies are poorly known. Basin-floor fans form extensive sheets, tens of kilometres across and 40-100 m thick, that onlap the basal sequence boundary basinward of the previous platform. Their upper surfaces are primarily defined by reflectors with high acoustic impedance contrasts and downlap of the overlying slope fan. They were deposited during periods of relative sea-level lowstand when the platform was exposed, and they most likely consist of terrigenous sands fed by incised river systems, the deposits of which are locally preserved on the platform (e.g., conglomerate in Figs $1,3)$. Slope fans form thick wedges above the basin-floor fans and pinch out against the slope of the previous platform. They generally have a mounded seismic character and locally display distinct "gull-wing" reflectors that indicate channel-levee complexes. The flanks of the mounds display subparallel reflectors interpreted as distal turbidite aprons. Slope fans consist of siltstone, shale, and minor sandstone. Prograding complexes form thick, progradational and aggradational lenses with well-defined sigmoidal clinoforms that onlap their basal sequence boundary at or near the previous platform margin and downlap basinward onto the slope fans. They are commonly the most voluminous depositional system; distal slope facies comprise calcareous siltstone and minor sandstone whereas proximal shallow-water facies comprise pelletal carbonates.

Transgressive deposits are commonly below seismic resolution. They consist of sandy, oolitic, and bioclastic grainstone and packstone, overlain by dark gray-green calcareous shale. Highstand deposits display discontinuous parallel reflectors across the platform, oblique progradational geometries at the platform margin, and downlap onto the lowstand prograding complex. They comprise back-reef, reef, and slope carbonates.

\section{SURFACE SEQUENCE STRATIGRAPHY}

Preliminary studies of conglomerates associated with reefal outcrops were undertaken to determine whether sequence-stratigraphy concepts could elucidate the temporal and spatial distribution of these facies (e.g., Holmes, 1991). Cobble to boulder conglomerates and sandstones were observed in two distinct relations with reef carbonates (Fig. 4): thick, valley-fill deposits incised at least $10 \mathrm{~m}$ into slope and platform facies (e.g., Van Emmerick and Mt. Behn Conglomerates, Fig. 1) and metre-scale units intercalated with platform facies (e.g., Stoney Creek, $110 \mathrm{~km}$ southeast of Mt. Behn, beyond area shown in Fig. 1). The valley-filling conglomerates represent alluvial-fan, braided-stream, and shallow-marine gravity-flow deposits that were transported across the exposed reef platform at times of lowered sea level, and their basal contact is a type 1 (Vail, 1987) sequence boundary. The intercalated conglomerates and carbonates are overlain and downlapped by reef and slope facies and are interpreted as transgressive, nearshore facies that record episodic, terrigenous influx perhaps related to active fault scarps in the hinterland.

Abundant siliciclastic sandstone was also observed within thick massflow deposits within successions previously interpreted as marginal-slope facies. We suggest that some of these units represent lowstand deposits basinward of the conglomerates discussed above.

\section{DISCUSSION}

This sequence analysis has identified major disconformities and at least eight relative sea-level cycles within the reef complex. Within each reef cycle, episodes of highstand carbonate deposition are punctuated by episodes of clastic-dominated sedimentation when the carbonate platform was subaerially exposed and incised by streams. These streams transported terrigenous sediments across the platform to basinal and slope fans basinward of the platform. This new concept of punctuated platform development leads to a new model of reef development (Fig. 5), which is significantly different from the outcrop model of Playford et al. (1989, Fig. 12). Their model of back-stepping and then advancing platform margins only depicts phases of highstand sedimentation in a long-term (secondorder) transgressive-regressive cycle and does not consider periods of lowstand sedimentation. In our new model, the "transgressive" Pillara and "regressive" Nullara cycles can each be seen to consist of successively onlapping depositional sequences that reflect shorter-term (third-order) relative sea-level cycles, and they are separated by a major relative sealevel fall that resulted in a marked basinward shift of facies. Whereas progradation of the highstand carbonate platforms is minor within sequences of the Pillara cycle (maximum 0.5-km progradation), highstand carbonate platforms within sequences of the Nullara cycle exhibit marked
Figure 2. Sequence interpretation of seismic lines indicated in Figure 1. Note that Frasnian-Famennian (F-F) sequence straddles Frasnian-Famennian boundary; lowstand deposits are Frasnian, and transgressive and highstand deposits are Famennian.

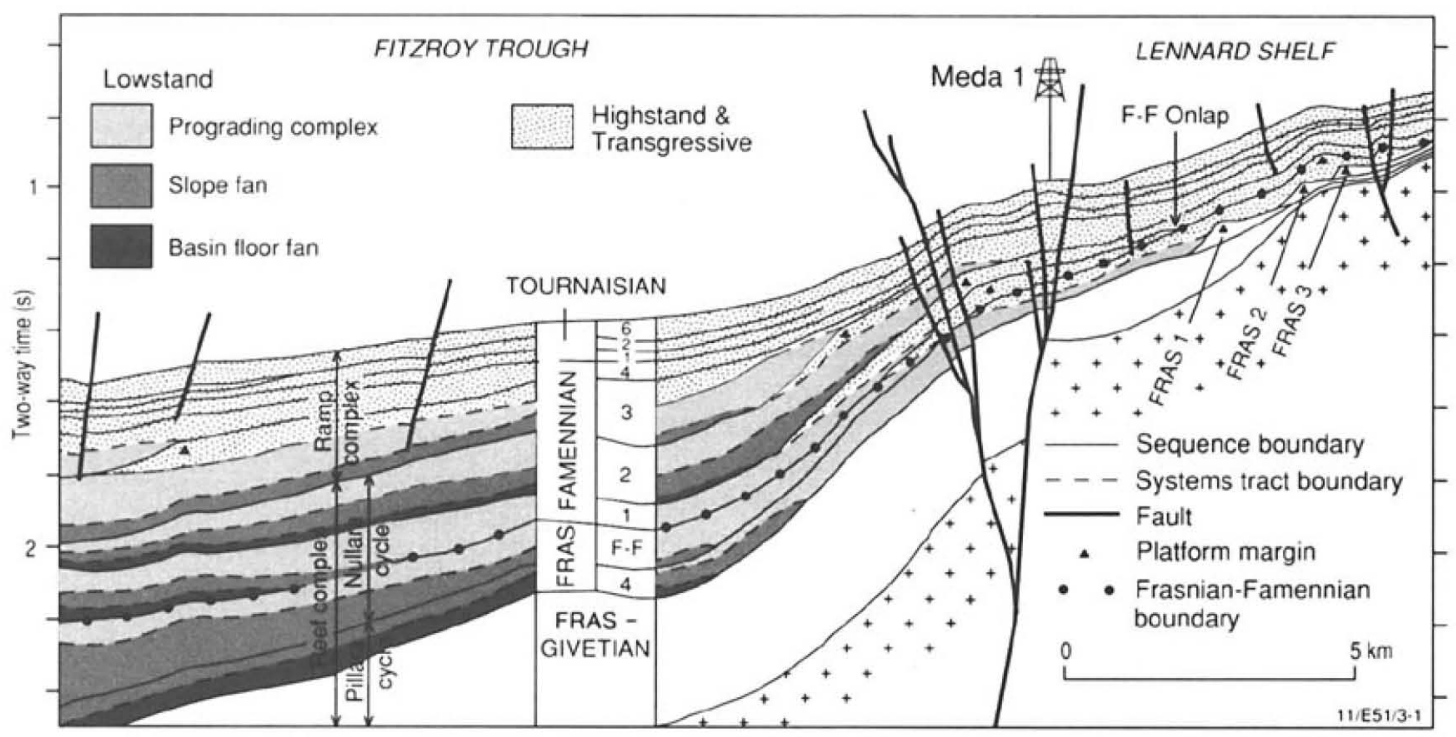




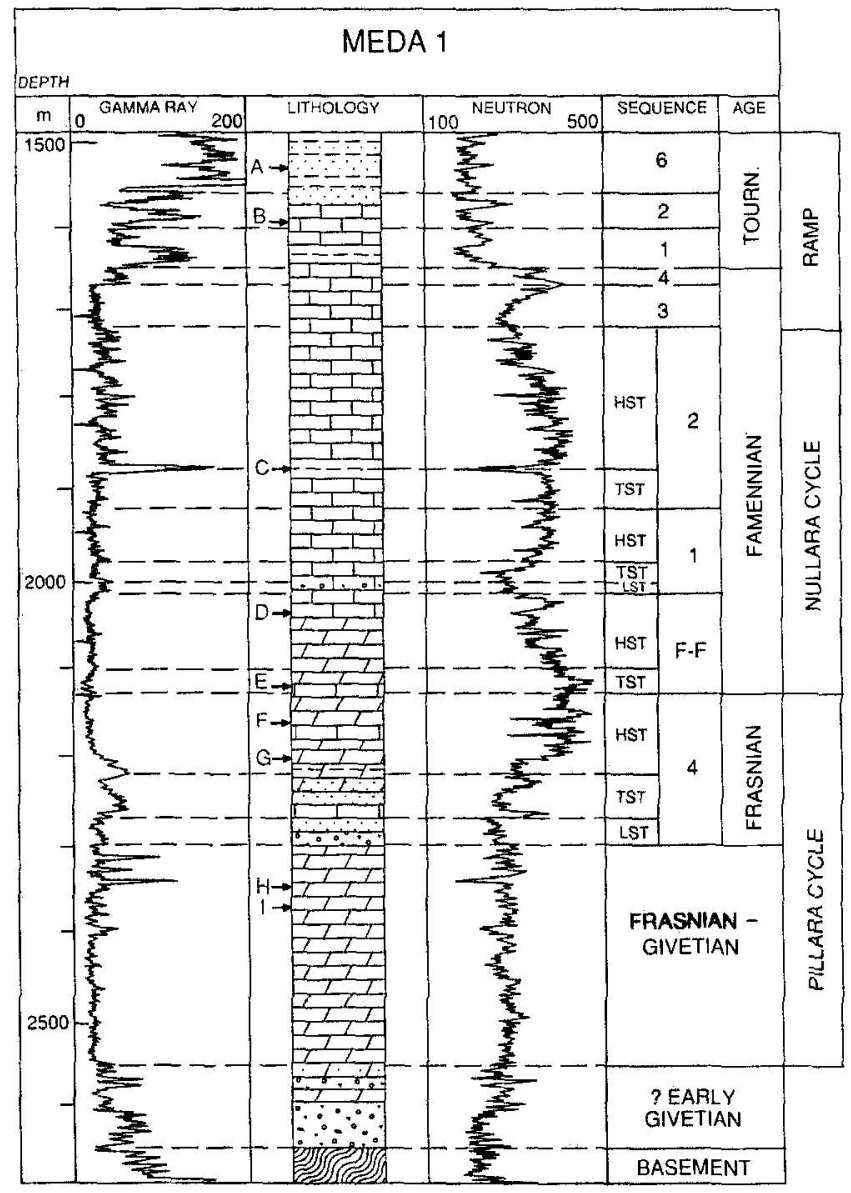

Figure 3. Sequence interpretation of Meda 1 well. Age-diagnostic samples: A-Tournaisian spores; B-Tournaisian conodonts, ostracods, spores, brachiopods; C-middle to late Famennian conodonts, marginifera to Early praesulcata Zone; D-early Famennian conodonts, Middle to Late triangularis Zone; E-early Famennian conodonts, triangularis Zone; F-late Frasnian ostracods, brachiopods; G-late Frasnian conodonts; H-lower Frasnian conodonts; I-Frasnian to Givetian conodonts. progradation (typically $2-5 \mathrm{~km}$ ), such that even though these sequences successively onlap landward, the terminal highstand platform margin extends progressively basinward for each successive sequence (Fig. 5).

Recent detailed biostratigraphic studies of the outcropping reef complex can now be seen in a new perspective. Becker et al. (1992) recognize several anoxic-hypoxic events in early Frasnian basinal and interreef facies, each event delineated by a thin interval of rich, hematized, goniatite faunas. They have related these events to periods of relative sea-level rise and noted that many of these anoxic-hypoxic intervals are succeeded by thicker intervals of coarse carbonate debris flows. We interpret these thin, anoxic-hypoxic intervals as condensed basinal sections (transgressive and highstand systems tracts) and suggest that the overlying debris flows represent proximal lowstand deposits of the succeeding sequence (we have

\section{A. VAN EMMERICK}

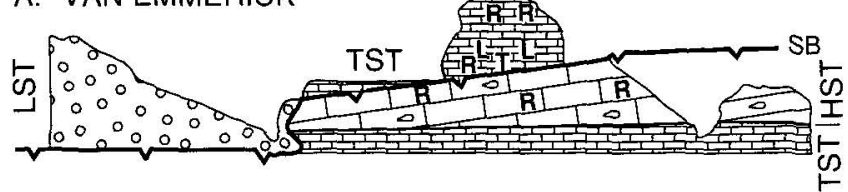

\section{B. STONY CREEK}

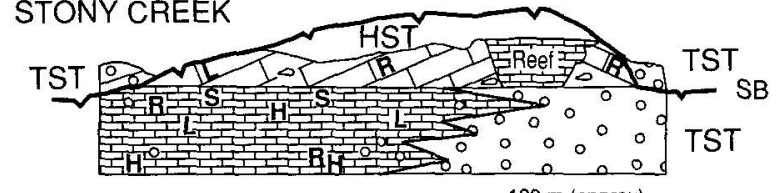

50 Siliciclastic conglomerate
Limestone
Carbonate debris

$\sim$ Sequence boundary (SB)

Figure 4. Schematic cross sections showing sequence interpretation of Devonian conglomerate and reef outcrops: A: Valley-fill conglomerate at Van Emmerick Range. B: Intercalated conglomerate and carbonate at Stony Creek $(170 \mathrm{~km}$ southeast of Van Emmerick Conglomerate, beyond area shown in Fig. 1).

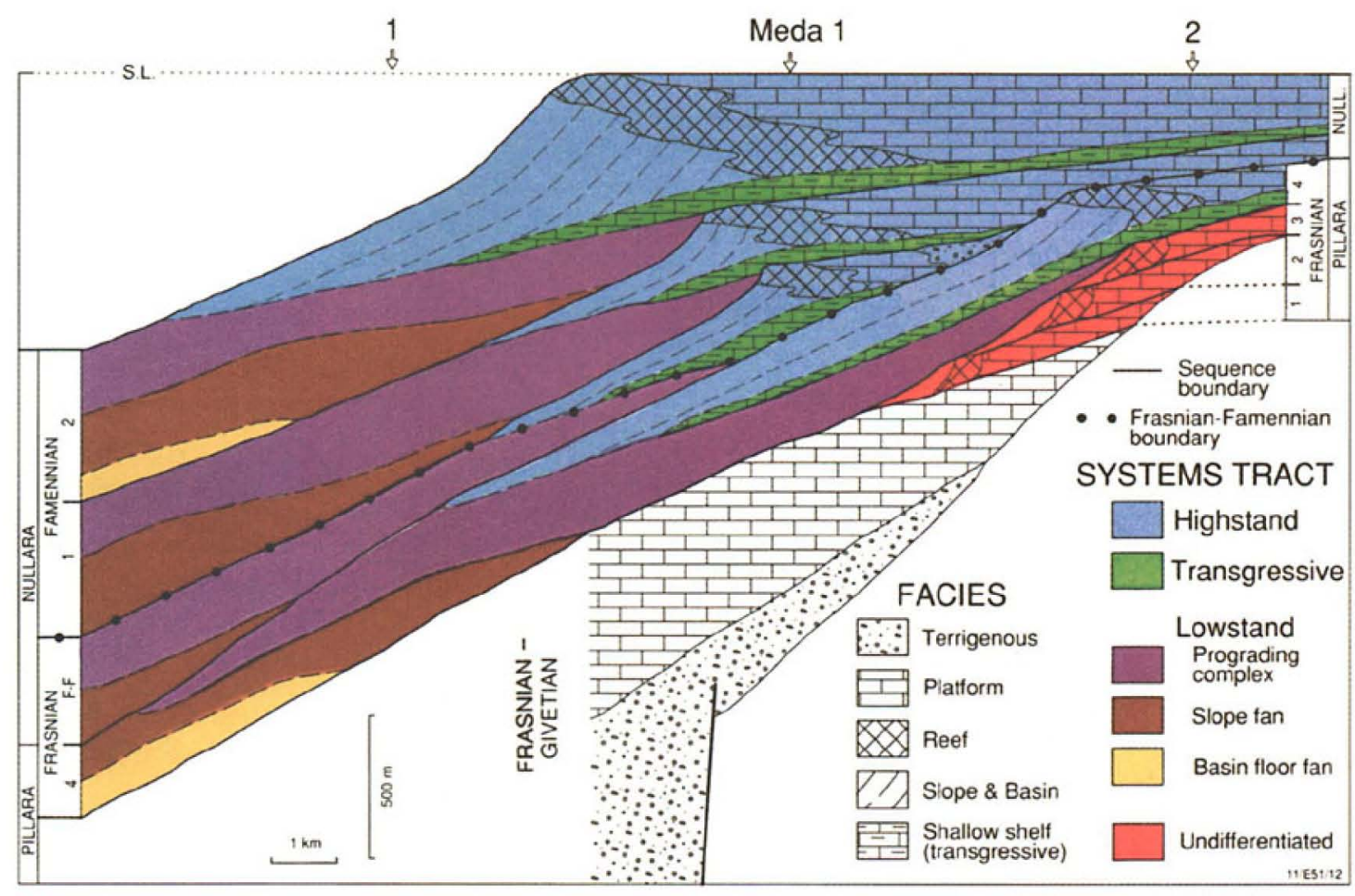

Figure 5. Sequence model of Frasnian-Famennian reef complex based on seismic and well data in Meda 1 well area. Facies are shown for transgressive and highstand deposits. Numbered arrows indicate locations referred to in text. 
observed numerous quartz pebbles in these debris flows). Consequently, the contact between an anoxic-hypoxic interval and the overlying debris flows is a sequence boundary.

Becker et al. (1992) were also able to date several stromatolitic horizons in the Frasnian-Famennian boundary interval, and they noted that these horizons are interspersed with "coarse-grained reef talus." They proposed that the stromatolite horizons represent hardgrounds and times of reduced detritus supply and interpreted them as regressive intervals. We suggest that the stromatolitic hardgrounds represent condensed deposits basinward of thicker transgressive and highstand platform facies and that the interspersed "reef talus" represents successive lowstand deposits eroded from the preceding highstand platform. Thus, both anoxic-hypoxic (Frasnian) and stromatolitic oxic (Famennian) intervals can be used to define sequences in outcrop. In this way, our subsurface studies and reef model can be integrated with, and facilitate reinterpretation of, previous outcrop studies.

Our sequence model also has important implications for the Frasnian-Famennian boundary that marks a global change in the composition of reef-building organisms. Biostratigraphic data at the Meda 1 well indicate that, in this platformal setting, the Frasnian-Famennian boundary lies at or near the base of the transgressive systems tract of the FrasnianFamennian sequence (Fig. 3), a situation where major faunal turnovers are likely to be recorded (Loutit et al., 1988). In more basinal settings where lowstand deposits are present and transgressive and highstand deposits are condensed (arrow 1, Fig. 5), the Frasnian-Famennian boundary probably lies within the condensed section above the lowstand deposits of the Frasnian-Famennian sequence, at or below the Famennian 1 sequence boundary. In more landward settings, where the Frasnian-Famennian sequence is absent because of the marked downward shift of coastal onlap at the beginning of the Nullara reef cycle, the Frasnian-Famennian boundary lies at the base of Famennian sequence 1 (arrow 2, Fig. 5). In summary, the Frasnian-Famennian boundary only coincides with the Pillara-Nullara cycle boundary in areas landward of Meda 1 ; it is conformable in basinal settings and marks a disconformity of increasing duration on proximal portions of the platform.

The Frasnian-Famennian boundary interval has been studied at several outcrop localities. At McWhae Ridge ( $250 \mathrm{~km}$ southeast of Meda 1), goniatites and conodonts indicate that the boundary interval is extremely condensed and that sedimentation was continuous across the boundary (Becker et al., 1991, section 371; Nicoll and Playford, 1993, sections 353, 354). Extreme condensation of these basinal deposits is also indicated by centimetre-scale magnetic reversals within an iridium-enriched Frutexites stromatolite bed (Hurley and Van der Voo, 1990) which lies $\sim 4 \mathrm{~m}$ above the Frasnian-Famennian boundary (Nicoll and Playford, 1993). Our sequence model suggests that the 16-m-thick deposits at McWhae Ridge (Becker et al., 1991, section 371) collectively represent part of Frasnian sequence 4 (17-25.2 m), the Frasnian-Famennian sequence (25.2-31.38 $\mathrm{m}$ ), and part of Famennian sequence 1 ( $31.38 \mathrm{~m}$ to top of section). The Frutexites bed is capped by and contains numerous crinoid holdfasts and is interpreted as a condensed section at the top of the Frasnian-Famennian sequence. Conodont data at this section (Nicoll and Playford, 1993) indicate that the base of our Frasnian-Famennian sequence lies at or near the base of the Palmatolepis linguiformis Zone and that the Famennian 1 sequence boundary lies within or at the top of the Palmatolepis crepida Zone.

In platformal facies in the Oscar and Napier Ranges, the FrasnianFamennian boundary corresponds to a subaerial erosion surface of several metres relief, with associated minor karstification (Playford, 1991; Playford et al., 1989). Our sequence model suggests that this surface overlies Frasnian sequence 4 and that the overlying Famennian carbonates represent our F-F sequence, or, if that sequence is absent owing to the marked basinward shift of coastal onlap at the beginning of the Nullara reef cycle, our Famennian sequence 1.

\section{ACKNOWLEDGMENTS}

Work by Christie-Blick and Holmes supported by the National Science Foundation and the Donors of the Petroleum Research Fund, administered by the American Chemical Society. We thank Phillip E. Playford for sharing his in-depth knowledge of the outcropping reef belt with us and for comments on an earlier draft of this paper; Robert S. Nicoll, Peter J. Jones, and Gilbert Klapper for discussions of biostratigraphic data and reexamination of microfauna samples from Meda 1 well; and Noel James and John Grotzinger for reviewing the manuscript. This study forms part of the joint Commonwealth-State National Geoscience Mapping Accord.

\section{REFERENCES CITED}

Becker, R.T., House, M.R., Kirchgasser, W.T., and Playford, P.E., 1991, Sedimentary and faunal changes across the Frasnian/Famennian boundary in the Canning Basin of Western Australia: Historical Biology, v. 5, p. 183-196.

Becker, R.T., House, M.R., and Kirchgasser, W.T., 1992, Devonian goniatite biostratigraphy and timing of facies movements in the Frasnian of the Canning Basin, Western Australia, in Hailwood, E.A., and Kidd, R.P., eds., High resolution of marine sequences: Geological Society of London Special Publication (in press).

Gibbs, A.D., 1984, Structural evolution of extensional basin margins: Geological Society of London Journal, v. 141, p. 609-620.

Holmes, A.E., 1991, Late Devonian carbonate-conglomerate association in the Canning Basin, Western Australia [abs.]: American Association of Petroleum Geologists Bulletin, v. 75, p. 596.

Hurley, N.F., and Van der Voo, R., 1990, Magnetostratigraphy, Late Devonian iridium anomaly, and impact hypotheses: Geology, v. 18, p. 291-294.

Kemp, G.J., and Wilson, B.L., 1990, The seismic expression of Middle to Upper Devonian reef complexes, Canning Basin: Australia Petroleum Exploration Association Journal, v. 30, p. 280-289.

Loutit, T.S., Hardenbol, J., and Vail, P.R., 1988, Condensed sections: The key to age determination and correlation of continental margin sequences, in Wilgus, C.K., et al., eds., Sea-level changes: An integrated approach: Society of Economic Paleontologists and Mineralogists Special Publication 42, p. 183-213.

Middleton, M.F., 1987, Seismic stratigraphy of Devonian Reef complexes, northern Canning Basin, Western Australia: American Association of Petroleum Geologists Bulletin, v. 71, p. 1488-1498.

Nicoll, R.S., and Playford, P.E., 1993, Upper Devonian iridium anomalies, conodont zonation and the Frasnian-Famennian boundary in the Canning Basin, Western Australia: Palaeogeography, Palaeoclimatology, Palaeoecology (in press).

Playford, P.E., 1980, Devonian "Great Barrier Reef" of the Canning Basin, Western Australia: American Association of Petroleum Geologists Bulletin, v. 64, p. 814-840.

Playford, P.E., 1991, Reef development and extinction in response to sealevel change in the Devonian of the Canning Basin [abs.]: American Association of Petroleum Geologists Bulletin, v. 75, p. 654.

Playford, P.E., Hurley, N.F., Kerans, C., and Middleton, M.F., 1989, Reefal platform development, Devonian of the Canning Basin, Western Australia, in Crevello, P.D., et al., eds., Controls on carbonate platform and basin development: Society of Economic Paleontologists and Mineralogists Special Publication 44, p. 187-202.

Posamentier, H.W., Jervey, M.T., and Vail, P.R., 1988, Eustatic controls on clastic deposition I-Conceptual framework, in Wilgus, C.K., et al., eds., Sea-level changes: An integrated approach: Society of Economic Paleontologists and Mineralogists Special Publication 42, p. 109-124.

Posamentier, H.W., Erskine, R.D., and Mitchum, R.M., 1991, Models for submarine-fan deposition within a sequence-stratigraphic framework, in Weimer, P., and Link, M.H., eds., Seismic facies and sedimentary processes of submarine fans and turbidite systems: New York, Springer-Verlag, p. $127-136$

Sarg, J.F., 1988, Carbonate sequence stratigraphy, in Wilgus, C.K., et al., eds., Sea-level changes: An integrated approach: Society of Economic Paleontologists and Mineralogists Special Publication 42, p. 155-181.

Vail, P.R., 1987, Seismic stratigraphy interpretation using sequence stratigraphy, Part 1: Seismic stratigraphy interpretation procedure, in Bally, A.W., ed., Atlas of seismic stratigraphy: American Association of Petroleum Geologists, Studies in Geology, v. 27, p. 1-10.

Van Wagoner, J.C., Mitchum, R.M., Campion, K.M., and Rahmanian, V.D., 1990, Siliciclastic sequence stratigraphy in well logs, cores, and outcrops: Concepts for high-resolution correlation of time and facies: American Association of Petroleum Geologists, Methods in Exploration Series No. 7, 55 p.

Manuscript received March 26, 1992

Revised manuscript received August 11, 1992

Manuscript accepted August 24, 1992 